ISSN : 2087-2461

PENANGGUNG JAWAB Dekan FIKOM Trimanah, M.Si

Sekretaris Fakultas

Dian Marhaeni K, M.Si

Ketua Penyunting Made Dwi Adnjani, M.Si

Sekretaris

Mubarok, M.Si

Bendahara

Parwati, SH

Dewan Penyunting

Edi Ismoyo, M.Si

Drs. Haryoso

Seksi Usaha

Endang Winarsih, S.Sos

Sirkulasi dan Distribusi

Palupi Satwika, Amd.

Alamat Redaksi

Fakultas Ilmu Komunikasi

Universitas Islam

Sultan Agung Semarang

Jl. Raya Kaligawe Km. 4

Po. Box 1054/SM

Semarang 50112

Telp. (024) 6583584

ext. $448 / 449$

Fax. (024) 6582455

email : jurnalfikom@yahoo.com
Konstruksi Teori Komunikasi Dalam Tafsir Al Qur'an Surat Al Fatihah

Mubarok

mubarok@unisula.ac.id

$110-127$

Inovasi Komunikasi Pemasaran Pada RRI Semarang

Agus Triyono

agustriyono7@gmail.com

128-136

Pengaruh Word of Mouth dan Brand Awareness terhadap Intensi Mengunjungi Tempat Wisata Ziarah Makam Sunan Kalijaga Demak

Santi Ratnawati

santirahmawati@ymail.com

$137-148$

Pengaruh Persepsi Downline Tentang Kualitas Jasa Upline Pada Multi Level Marketing Tianshi Terhadap Loyalitas Downline di Malang

(Studi pada jaringan Akhmad Fidzan)

Devi Purnamasari

devi.purnamasari9@g mail.com

149-163

Manajemen Krisis Polri dalam Kasus Penyerangan Lembaga Permasyarakatan Cebongan Sleman Daerah Istimewa Yogyakarta

Iva Anjar Pawestri

iva.anjar89@yahoo.co.id

$164-180$

Identitas Diri Remaja Melalui Status Sosial Facebook

Muna Madrah

munamadrah@unissula.ac.id.

Made Dwi Adnjani

made@unissula.ac.id

$181-198$

Efektifitas Pelaksanaan Kebijakan Joko Widodo dalam Mengentaskan Kemiskinan (Studi Opini Pemegang Kartu Jakarta Sehat dan Kartu Jakarta Pintar di DKI Jakarta)

Indah Suryawati

indahsuryawati_2121@yahoo.com 199-218 


\title{
IDENTITAS DIRI REMAJA MELALUI STATUS SOSIAL FACEBOOK
}

\author{
Oleh : \\ Muna Madrah \\ munamadrah@unissula.ac.id. \\ Made Dwi Adnjani \\ made@unissula.ac.id
}

Fakultas Ilmu Komunikasi Universitas Islam Sultan Agung (UNISSULA)

\begin{abstract}
Abstrak
Dunia cyber menjadi dunia baru layaknya dalam kehidupan nyata menawarkan hal-hal yang bisa dilakukan pada dunia nyata. Mulai dari chatting, conference, berbelanja sampai mencari jodoh bisa dilakukan di dunia maya ini, bahkan kuliah saat ini bisa dilakukan melalui dunia maya ini. Hanya dengan "click" kita diajak untuk memasuki "ruang” dimana kita bisa mencari apa saja yang kita inginkan, tanpa dibatasi oleh jarak dan waktu yang di sebut oleh Mc Luhan sebagai "Global Village”. Dari berbagai fenomena tersebut di atas, maka menjadi penting untuk meneliti mengenai konstruksi sosial media dan bagaimana identitas diri remaja yang dimunculkan melalui status media sosial facebook.

Penelitian ini adalah penelitianyang bersifat kualitatif dengan menggunakan pendekatan grounded untuk memahami bagaimana remaja mengkonstruksi identitas dirinya melalui statusstatus yang diunggah pada situs sosial media facebook. Penelitian ini difokuskan pada remaja usia 14 -18 tahun karena pada usia ini mereka lebih sering melakukan update status setiap hari. Hasil penelitian menunjukkan bahwa perangkat facebook memungkinkan setiap pengguna dan atau pemilik akun di facebook disediakan form atau borang untuk menuliskan profil diri mereka seperti nama, nama kecil, tempat tanggal lahir, pendidikan, hobi, sampai pada kutipan yang disenangi olehnya. Fasilitas facebook tersebut memungkinkan seseorang mengkonstruk dirinya melalui perantaraan teks baik itu dalam pengertian kumpulan kata maupun gambar yang pada akhirnya memberikan kepingan-kepingan gambar bagaimana subyek pemilik akun facebook itu. Implikasi dari penelitian ini adalah Karena identitas diri remaja di facebook cenderung membebaskan dirinya dari pemahaman kesejarahan tentang identitas yang selama ini berlaku di dunia nyata, maka orang tua juga perlu untuk lebih memahami teknologi sehingga memungkinkan untuk melakukan pendampingan dan pemantauan terhadap konstruksi identitas yang dibentuk anak-anaknya.
\end{abstract}

Kata kunci : Konstruksi Sosial, Identitas Diri, Media Sosial

Abstract

Cyber world come into a new world like in real life offers things that can be done in the real world. Starting from the chat, conferencing, shopping can be done to find a mate in the virtual world, even learning in campus currently can be done through the virtual world. Only with a "click" we are invited to enter the "space " where we can find what we want, without being restricted by distance and time of the call by Mc Luhan as a "Global Village. The various phenomena mentioned above, it becomes important to examine the social construction of media and how the adolescent identity generated through social media facebook status .

This research is a qualitative study using a grounded approach to understanding how adolescents construct their identity through statuses uploaded on social media site Facebook. This study focused on adolescents aged 14 -18 years because at this age they are more frequent 
status updates every da. The results showed that facebook allows each user device and the owner of the account on Facebook or supplied form or accreditation forms to write down their personal profile such as name, first name, date of birth, education, hobbies, until the quote is favored by him. The Facebook facility allows one construct themselves through the mediation of either the text in terms of a collection of words and images which in turn gives the pieces a picture of how the subject that the owner of the Facebook account. The implication of this study is the identification Because teenagers on Facebook tends to free itselffrom the historical understanding of identity that has been applicable in the real world, parents also need to better understand the technology making it possible to provide guidance and monitoring of the construction of identity is formed by their children.

\section{Keywords: Social Construction, Self Identity, Social Media}

\section{Pendahuluan}

Internet sudah bukan menjadi barang asing lagi diantara kita. Temuan teknologi terkini tersebut telah merambah ke seantero dunia dengan cepat dan mempengaruhi kehidupan kita. Melalui internet dengan dunia cyber nya (cyberspace) bisa dikatakan bahwa manusia telah sampai pada sebuah penjelajahan global melampaui batas-batas yang tidak mungkin dilakukan pada abad sebelumnya. Internet dewasa ini dianggap sebagai penyelesaian masalah terhadap segala keterbatasan manusia untuk mengembara dalam berbagai bentuk realitas tanpa batas (Astar Hadi:2005:4)

Dalam sebuah penelitian, Rainie (2006) sebagaimana dipaparkan oleh Kamaluddin (2011) mengemukakan bahwa pengguna internet lebih dari 57,8 juta orang mengikuti laju pertumbuhan layanan teknologi broadband dan jaringan seluler. Pemakaian telephone seluler mencapai angka 170 juta orang dan angka pengguna komunikasi bergerak (mobile telecommunications) akan akan berlipat $50 \%$ dalam waktu dua atau tiga tahun ke depan.

Dunia cyber menjadi dunia baru layaknya dalam kehidupan nyata menawarkan hal-hal yang bisa dilakukan pada dunia nyata. Mulai dari chatting, conference, berbelanja sampai mencari jodoh bisa dilakukan di dunia maya ini, bahkan kuliahpun saat ini bisa dilakukan melalui dunia maya ini. Hanya dengan "click" kita diajak untuk memasuki "ruang" dimana kita bisa mencari apa saja yang kita inginkan, memasuki "komunitas" yang memiliki minat yang sama dengan kita, atau malah membentuk "komunitas" baru sesuai dengan keinginan kita, tidak dibatasi oleh jarak dan waktu yang disebut oleh Mc Luhan sebagai "Global Village".

Sebetulnya apa yang dimaksud dengan cyberspace? Sebagai sebuah fenomema baru dalam jagat raya informasi dan komunikasi global, cyberspace menjadi sulit didefinisikan secara untuh. Hal ini di karenakan kecenderungan sifatnya yang plural dan dipenuhi oleh over produksi citra, simbol, dan tanda-tanda yang sarat makna yang seringkali tumpang tindih (Astar Hadi : 2005). Istilah cyberspace pertama kali dipakai oleh William Gibson dalam novelnya Neoromancer, dalam novel tersebut Gibson menggambarkan cyberspace sebagai pemandangan yang dihasilkan komputerkomputer yang di tancapkan langsung yang kadang-kadang juga berupa soket-soket yang langsung di tanamkan di otak (Antariksa : 1999). Bagi Gibson bukan sistem jaringanya yang menjadi penting akan tetapi cyberspace adalah sebuah pengalaman masyarakat yang memakai teknologi baru untuk melakukan sesuatu yang sebenarnya secara genetik telah di programkan yaitu komunikasi. Cyberspace menerangkan sebuah tempat yang tidak ada di manapun, di mana e-mail hilir mudik, transfer elektronik dan pesan-pesan digital lainya berlalu lalang dan situs-situs World Wide Web (www) diakses. Ogden menggambarkan cyberspace sebagai suatu tempat tanpa ruang secara konseptual di mana kata-kata, hubungan 
Made Dwi Adnjani

antar manusia data, status dimunculkan oleh orang-orang yang menggunakan teknologi komunikasi dengan perantara computer (Barker 2000: 327), cyberspace sebagai bentuk jaringan komunikasi dan interaksi global (Hadi:2005:7), sedang Yasraf Amir Piliang (2004:16) mendefinisikan sebagai ruang halusinatif yang dibentuk melalui media digital, yang menghasilkan pengalamanpengalaman halusinasi. Cyberspace dengan bangga menawarkan sistem nilai dan bentuk komunitas sendiri, yaitu yang disebut komunitas virtual.

Fokus sosiologi telah mengalami transformasi dari masyarakat (society) ke mobilitas (mobility). Dalam pandangan Tourine (1988) sebagaimana dipaparkan Gumilar (2012) bahwa basis tradisional sosiologi yaitu masyarakat telah ketinggalan zaman. Para pendiri sosiologi telah meletakkan dasar-dasar penting dalam penelitian tentang masyarakat, fakta-fakta sosial sebagaimana dipaparkan Durkheim, determinasi ekonomi Marx ataupun gagaran rasionalisasi weber (Ritzer \& Goodman: 2004) adalah alat-alat analisa yang masih relevan di pakai. Sebagai ilmu pengetahuan yang berkembang tentu saja sosiologi tidak dapat secara kaku menetapkan preasumsi-preasumsi tentang masyarakat, dimana definisi masyarakat, society, groups telah bertransformasi dalam bentuknya yang baru. Masyarakat tidak lagi terbentuk dengan pola linier seagaimana dibayangkan oleh para sosiolog modern. Pola yang kompleks telah berkembang sejurus dengan perkembangan teknologi dan teknologi informasi yang cepat, yang tidak pernah terbayangkan sebelumya.

Perkembangan pemilik account sosial facebook misalnya dapat kita lihat pada tabel berikut:

Tabel 1.1 Perbandingan pengguna facebook 2011-2012

\begin{tabular}{|c|c|c|c|}
\hline Rangking & Negara & $\begin{array}{c}\text { Jumlah pemilik } \\
\text { account } \\
\mathbf{2 0 1 1}\end{array}$ & $\begin{array}{c}\text { Jumlah pemilik } \\
\text { account 2012 }\end{array}$ \\
\hline 1 & Amerika & 154.040 .460 & 168.800 .560 \\
\hline 2 & Indonesia & 39.568 .620 & 51.497 .740 \\
\hline 3 & India & 33.587 .640 & 62.697 .100 \\
\hline 4 & Turki & 29.951 .960 & 33.136 .140 \\
\hline 5 & Inggris & 29.942 .160 & 33.173 .320 \\
\hline 6 & Meksiko & 28.150 .240 & 40.225 .740 \\
\hline 7 & Philipina & 26.056 .340 & 30.080 .580 \\
\hline 8 & Brasil & 24.921 .480 & 64.688 .240 \\
\hline 9 & Perancis & 22.582 .160 & 25.654 .960 \\
\hline 10 & Jerman & 20.538 .540 & 25.345 .920 \\
\hline
\end{tabular}

Sumber http://www.checkfacebook.com/

Lebih dari setengah abad kebelakang, Amerika Serikat dan Negara-negara ekonomi maju secara gradual telah membuat perubahan kedalam apa yang biasanya disebut masyarakat informasi "era informasi" (Fukuyama: 2000). Dan keberadaan internet sebagai salah satu media masa yang bertujuan memberikan informasi yang seluas-luasnya kepada khalayak.

Kita sedang berada pada sirkuit dimana kita dituntut untuk berpacu menerima dan mereproduksi informasi-informasi baru. Sehingga sangat sulit lagi di bedakan mana informasi-informasi yang asli dan mana yang salinan. Hampir tidak ada lagi originalitas 
Made Dwi Adnjani

sebuah informasi. Dengan jaringan kerja yang begitu luas dan kemampuan akses yang cepat dengan jarak yang luas teknologi ini menawarkan sisi lain dari komunikasi yang mendunia. Sekali lagi dengan "menekan tombol" kita bisa mengirimkan, mengkopi atau mengunduh dan menyebarkan kembali informasi tersebut bersamaan dengan munculnya informasi itu sendiri. Bahkan kehidupan yang paling pribadi dari para selebritis yang mungkin tidak dapat di akses melalui media informasi lainya seperti TV atau radio beredar dengan mudah pada situssitus cyber. Simak saja video-video mesum dari beberapa artis kita, cukup dengan "click" dan kita disuguhi tayangan bebas tanpa sensor. Berita tentang drama politik di senayan dapat disajikan pada kita pada "real time"nya.

Internet dalam sifatnya sebagai media informasi yaitu media yang sama-sama tertuju pada khalayak dan kemajemukan yang luas tidak dapat dipisahkan dengan media komunikasi massa lainya (misalnya televisi, surat kabar, radio), akan tetapi ada perbedaan karakteristik yang cukup signifikan antara internet dan media-media informasi lainya. Sejak teknologi ini dikembangkan pada sekitar era 80-an disamping kemampuanya menyediakan perubahan informasi yang radikal dan universal dengan jaringan kerja yang begitu luas dan kemampuan akses yang begitu cepat internet menawarkan sisi komunikasi yang mendunia (Hadi:2005).

Pada dasarnya kemampuan internet dalam menciptakan realitas virtual atau pengalaman ruang yang dihasilkan oleh teknologi komputer terdapat juga pada teknologi televisi, telepon atau film. Tetapi internet menampilkan virtualitas yang berbeda, dimana kontrol atau kendali komunikasi terletak pada pemakai (user) bukan pada pencipta atau medium komunikasi. Sifatnya yang senantiasa on line tentu saja membawa pada sifat interaktif dimana memungkinkan semua pihak dapat berhubungan dan berinteraksi setiap saat, yang memungkinkan partisipasi pemakai begitu tinggi dan kompleks.
Mau tidak mau generasi yang lahir pada abad ini adalah generasi "online". Di Indonesia warnet-warnet tumbuh bagai jamur dimusim hujan menggantikan "wartel" di era 1980-1990-an. Anak-anak terbiasa dengan video game online dan berkompetisi dengan berbagai orang di penjuru dunia. Rainie (2006) dalam penelitiannya menyebutkan data-data sebagai berikut:

Cyber Generation Phenomenon

\section{0 hours of videogame playing}

\section{Exchange of 250.000 emails}

\section{Instant messages}

\section{0,000 hours of cellphone use}

\section{3,500 hours of time online}

Secara sosiologi telah terjadi pergeseran dalam struktur masyarakat on line yang juga tentu saja bentuk-bentuk interaksi sosial yang di bangun oleh generasi on line ini. Sekarang ini, apakah masih penting memasukkan "kontak fisik" ke dalam prasyarat terjadinya interaksi sosial?

Teknologi telah membentuk karaktersitik masyarakat cyber, sebagai contoh keintiman interaksi antar individu di dunia maya, belumlah tentu terjadi pada dunia nyata. Interaksi bias saja terjadi tanpa ekspresi dan tanpa rasa dan menguap begitu saja dalam beberapa detik. Apa yang terjadi pada generasi on line? pengejawantahan interaksi seorang anak dengan on line game yang memungkinkan mereka menghujat, membunuh lawan tanpa "rasa" apapun dapat kita saksikan pada meningkatnya kasus tawuran pelajar. Kasus perkosaan anak dan bunuh diri pada anak dan remaja. Tentunya perlu penelitan dan kajian sosiologi mendalam atas fenomena tersebut. Sosiologi kiranya dapat memberikan solusi dengan rekonstruksi norma, etika, budaya pada masyarakat cyber. Tampaknya agak sulit diterapkan dimana pada masyarakat cyber batas-batas definisi society, groups dan culture tidak ada lagi. 
Sebagai situs jejaring sosial Facebook merupakan media yang bisa dipakai oleh audiens untuk melakukan self-discosure. Artinya, audiens kini dapat mengungkapkan informasi personalnya kepada publik sekaligus bisa menetapkan beragam kriteria yang diinginkan bagi mereka yang ingin menjalin hubungan dengannya. Self-disclosure atau pengungkapan diri dipandang penting, karena (1) munculnya perilaku positif mengenai diri sendiri maupun terhadap orang lain dan (2) pengungkapan diri menegaskan arti penting dari hubungan yang sedang terjalin dengan orang lain (sebagaimana dicontohkan Derlega dan Berg, 1987).

TidakdapatdipungkiribahwaFacebook merupakan situs pertemanan atau jaringan sosial yang belakangan ini berkembang sangat cepat dibanding situs pertemanan lainya. Facebook menawarkan banyak vitur yang ramah pengguna, dimana pengguna dapat bergabung dan terhubung dengan komunitas lain serta melakukan interaksi. Perkembangan Facebook di Indonesia sangat cepat bahkan tercepat di Asia Tenggara sehingga mendapat julukan the Republic of Facebook (Putra: 2009).

Facebook digunakan hampir semua lapisan usia, dari anak-anak tingkat SD ketika mereka mulai bisa membaca sampai orang dewasa. Melalui Facebook setiap pengguna dapat mengunggah status, mengganti profil, menggunggah foto, menandai orang lain. Fitur-fitur tersebut sangat interaktif dan membuat adiktif banyak pengguna. Apalagi teknologi komunikasi telah memungkinkan penjelajahan dunia maya melalui handphone. Situs-situs sosial media didisain khusus bagi para pengguna perangkat bergerak yang memudahkan pengguna selalu terhubung dengan dunia.

Pola interaksipun berubah mengikuti perkembangan teknologi. Pergaulan remaja juga tidak lepas dari fenomena tersebut. Saling "colek", "menandai" dan membagi informasi dalam dunia facebook sudah menjadi bagian dari realitas sosial. Mencermati perkembangan facebook, maka menjadi penting untuk meneliti mengenai konstruksi sosial media dalam hal ini facebook, sehingga perumusan masalah dalam penelitian ini adalah : Bagaimana identitas diri yang dibangun oleh remaja melalui status-status yang diunggah dalam situs jejaring sosial facebook.

\section{Metodologi Penelitian}

Penelitian ini adalah penelitian yang bersifat kualitatif dengan menggunakan pendekatan grounded untuk memahami bagaimana remaja mengkonstruksi identitas dirinya melalui status-status yang diunggah pada situs sosial media facebook. Penelitian akan difokuskan pada remaja usia $14-18$ tahun dimana pada usia ini remaja mengalami perubahan fisik dan mental yang cepat. Unit analisa yang dipakai adalah individu yaitu remaja yang aktif di jejaring sosial media facebook.

\section{Pembahasan}

Masa remaja merupakan fase perkembangan manusia. Manusia pada fase ini mengalamiperubahan atau peralihan dari masa kanak-kanak ke fase dewasa. Perubahan tersebut meliputi fisik dan mental yang cepat, sehingga membutuhkan kemampuan penyesuaian diri untuk menghadapi perubahan tersebut. Perubahan yang cepat tersebut lalu melahirkan energi besar yang harus disalurkan oleh remaja (Whandie: 2008 dalam Dewi: 2009).

Pada masa remaja juga terjadi beberapa perubahan psikis yang cukup drastis, antara lain perubahan peran dari masa anakanak ke masa remaja, penyesuaian terhadap lingkungan sosial, interaksi dengan teman sebaya, rasa sosial dan tanggung jawab, serta perkembangan identitas diri (Yudianto: 2008 dalam Judhita: 2011).

\section{Remaja dan Identitas Diri}

Secara lebih khusus, Erikson (dalam Dewi: 2009) menyebutkan bahwa tugas 
Made Dwi Adnjani

terpenting bagi remaja adalah mencapai identitas diri yang lebih mantap melalui pencarian dan eksplorasi terhadap diri dan lingkungan sosial. Krisis identitas umumnya akan terjadi sebelum identitas diri terbentuk. Remaja mengalami krisis identitas karena merasa sudah terlalu besar untuk dikategorikan sebagai anak-anak, namun belum bisa dikategorikan dalam kelompok dewasa.

Mereka yang berhasil memperoleh identitas diri yang sehat mencapai suatu keadaan yang disebut fidelity. Menurut Erikson (dalam Dewi :2009), fidelity yaitu suatu kelegaan karena kita mengenal siapa diri kita, tempat kita dalam masyarakat dan kontribusi macam apa yang bisa kita sumbangkan untuk masyarakat - Sebaliknya, mereka yang gagal memiliki suatu identitas diri akan gelisah karena tidak jelasnya identias diri mereka. Orang-orang ini bisa menjadi drifter, si pengembara, atau si penolak (mereka bisa menolak untuk mempunyai identitas diri, menolak definisi masyarakat tentang anggota masyarakat) dan mereka hidup sendiri bahkan ketika ada di tengah masyarakat (Dewi:2009). Erikson mempercayai bahwa kenakalan terutama ditandai dengan kegagalan remaja untuk mencapai integritas yang melibatkan berbagai aspek-aspek peran identitas diri (Santrock: 2003).

Selanjutnya Erikson (dalam Santrock :2003) mengatakan remaja yang memiliki masa balita, masa kanak-kanak, atau masa remaja yang membatasi mereka dari berbagai peran sosial yang dapat diterima atau yang membuat remaja merasa bahwa mereka tidak mampu memenuhi tuntutan yang dibebankan pada mereka, mungkin akan memilih perkembangan identitas diri yang negatif. Identitas diri didefinisikan sebagai keanggotaan dalam sebuah komunitas yang menyebabkan seseorang merasa terlibat, termotivasi, berkomitmen dan menjadikannya rujukan atau pertimbangan dalam memilih dan memutuskan sesuatu (Fearon:1999 dalam Dewi:2009). Hal ini sesuai dengan teori yang dikemukakan oleh Erikson. Erikson memberikan penekanan pada pengaruh sosial dalam perkembangan seorang individu. Penerimaan identitas diri terjadi bila ada kecocokan timbal balik antara individu dengan lingkungannya (Muss : 1996).

Permasalahan akan muncul ketika remaja memperlihatkan suatu identitas diri yang tidak diinginkan oleh orangtua dan lingkungannya. Identitas diri seperti ini oleh Erikson (dalam Steinberg, 2002, h. 275) disebut identitas diri negatif (negative identity). Selain pengaruh teman sebaya, identitas diri negatif juga dipengaruhi oleh faktor modeling. Bandura (dalam Sarwono, 1999, h. 313) mengatakan bahwa perilaku anti sosial atau kenakalan remaja adalah suatu hal yang dipelajari dalam kehidupan seharihari dari model yang dilihat dalam keluarga, dalam lingkungan kebudayaan setempat atau melalui media massa. Mengamati seorang model yang berpengaruh (misalnya orangtua, seseorang yang berstatus atau berkompetensi tinggi, atau tokoh TV yang populer) bisa menyebabkan diperolehnya perilaku yang diobservasi, bahkan bila perilaku model itu belum mendapat penguatan. Semakin positif akibat perilaku agresif itu bagi sang model, semakin besar kemungkinannya untuk ditiru oleh sang pengamat (Krahe :2005).

\section{Konstruksivisme}

Ide dasar semua teori dalam paradigma makro sosiologi adalah gagasan bahwa bentuk-bentuk kehidupan berkembang dari satu bentuk ke bentuk lain melaui mata rantai transformasi dan modifikasi yang tidak pernah terputus (Sanderson:2010). Definisi sosial memandang bahwa manusia adalah aktor yang kreatif dari realitas sosialnya (Ritzer:1992). Hal ini menggambarkan bahwa tindakan manusia tidak selalu ditentukan oleh normanorma, kebiasaan, nilai-nilai yang semua itu tercakup pada fakta sosial yang dapat kita lihat dalam struktur pranata sosial.

Dalam proses sosial, manusia dipandang sebagai pencipta realitas sosial yang bebas dalam dunia sosialnya. Manusia memiliki kebebasan untuk bertindak diluar 
batas kontrol struktur dan pranata sosial. Sedangkan pada pandangan konstruktivisme, realitas merupakan konstruksi sosial yang diciptakan oleh individu. Sudah merupakan pengakuan luas terhadap eksistensi individu, bahwa individu menjadi panglima dalam dunia sosialnya yang dikonstruksikan berdasarkan kehendaknya. Meskipun Ritzer mengatakan bahwa pandangan tersebut merupakan pandangan yang beraliran liberal ekstrem.

Gagasan konstruktivisme telah muncul sejak Sokrates mengemukakan adanya jiwa dalam tubuh manusia, atau sejak Plato memperkenalkan konsep akal budi dan ide (Bertens 1993). Setelah itu Aristoteles memperkenalkan istilah "informasi, relasi, individu, substansi, materi, esensi dan sebagainya. Aristoteles pula yang memperkenalkan istilah "Cogoto, ergo, sum" yaitu "saya berfikir maka saya ada" yang merupakan dasar kuat bagi perkembangan konsepsi kontruksivisme sampai saat ini.

Menurut Suparno ada tiga macam konstruktivisme. Pertama, konstruktivisme radikal yang hanya dapat mengakui apa yang dibentuk oleh pikiran kita. Para pemikir konstrivisme radikal mengesampingkan hubungan antara pengetahuan dan kenyataan sebagai suatu kriteria kebenaran. Bagi mereka pengetahuan tidak merefleksikan suatu realitas ontologis obyektif, akan tetapi lebih pada realitas yang dibentuk atas dasar pengalaman seseorang. Pengetahuan selalu merupakan konstruksi dari individu yang mengetahui dan tidak dapat ditransfer kepada individu yang lain yang pasif. Konstruksi harus dilakukan sendiri terhadap pengetahuan tersebut, sedangkan lingkungan adalah sarana terjadinya lingkungan konstruksi.

Kedua adalah konstruktivisme hipotesis yang berpandangan bahwa pengetahuan adalah hipotesis dari sebuah struktur realitas yang mendekati realitas dan menuju pada pengetahuan yang hakiki.

Konstruktivisme yang ketiga adalah konstruktivisme biasa yang mengambil semua konsekwensi konstruktivisme dan memahami pengetahuan sebagai gambaran dari realitas itu. Konstruktivisme biasa lalu memandang pengetahuan individu sebagai suatu gambaran yang dibentuk dari realitas objek dalam dirinya sendiri (Suparno dalam Bungin: 2008). Konstruktivisme yang seperti inilah yang disebut oleh Berger dan Luckman sebagai konstruksi sosial.

$$
\text { Dalam konteks masayarakat, }
$$
sebagaimana disampaikan M. Douglas (Journet dalam Dortier: 2004) kita tidak bisa memilah masyarakat manusia menjadi dua lingkaran yaitu yang afektif (holistik) dan yang rasional (individualistik). Douglas berpendapat bahwa semua pelaku atau aktor manusia mempunyai hubungan yang yang diperhitungkan secara bersama-sama yang seolah tampak sebagai sesuatu yang bersifat sekehendak pribadi yang dianggap "benar" Inilah yang disebut sebagai institusi, dimana sekelompok manusia melakukan legitimasi secara kolektif.

Memakai bahasa Durkheim, $\mathrm{M}$. Douglas menjelaskan klasifikasi-klasifikasi primitif untuk mengembangkan argumen utama. Dalam esaynya Douglas menjelaskan bahwa masyarakat bukanlah bukan kumpulan (kolektif) yang terkait dengan prefensi melalui afeksinya. Melainkan oleh batas 'frame' atau bingkai pemikiran umum yang dimiliki secara bersama. Maka dari itu dia menyetujui untuk mencari sebuah deskripsi yang apik tentang efek-efek kognitif dalam institusi yaitu teori tentang pengetahuan yang sah.

Bagaimana kita bisa berpendapat bahwa pengetahuan adalah sebuah konstruksi sosial? Apa yang telah disampaikan Douglas menunjukan beberapa lapis yang masingmasing menunjukan sifat sosial tersebut, yaitu: selektivitas, fungsionalitas dan legitimasi.

Dalam sebuah institusi modern, ilmu pengetahuan sebagai tempatnya penemuan yang menjadi kekayaan yang sangat bernilai. Akan mengherankan jika sebuah ide tertentu telah dirumuskan. Agar dapat dianggap benar maka pemikiran-pemikiran/ ide harus memiliki daya tarik bagi masyarakat yang 
menerimanya.

Konstruktivisme memandang ilmu sosial sebagai analisis sistematis atas "social meaningful action" melalui pengamatan langsung terhadap aktor sosial dalam seting yang alamiah agar dapat memahami dan menafsirkan bagaimana aktor sosial mencipta dan memelihara dunia sosial. Paradigma konstruktivisme merupakan antitesis terhadap paham yang menempatkan pentingnya pengamatan dan obyektivitas dalam menemukan suatu realitas atas ilmu pengetahuan. Secara ontologis paradigma ini menyatakan bahwa realitas itu ada dalam beragam bentuk konstruksi mental yang didasarkan pada pengalaman sosial. Kerenanya realitas yang diamati oleh seseorang tidak dapat digeneralisasi kepada semua orang, Atas dasar filosofis ini aliran konstruktivisme menyatakan bahwa hubungan epistimologis antara pengamat dan objek merupakan satu kesatuan, subyektif dan merupakan hasil perpaduan interaksi antara keduanya (Salim:2006:71)

Tugas pokok sosiologi pengetahuan adalah menjelaskan dialektika antara diri (self) dengan dunia sosiokultural. Dialektika ini melalui tiga tahapan proses simultan yaitu : Pertama, eksternalisai (penyesuaian diri) dengan dunia sosiokultural sebagai produk manusia. Kedua, obyektivasi yaitu interaksi yang terjadi dalam dunia intersubyektif yang dilembagakan atau mengalami proses institusionalisas. Ketiga, internalisasi sebuah proses dimana individu mengoidentifikasikan dirinya dengan lembaga-lembaga sosial atau organisasi sosial tempat individu menjadi anggotanya. (Berger : 1991).

Ketiga momen dialektika ini memunculkan sebuah proses konstruksi sosial yang dilihat dari segi asal mulanya merupakan asil ciptaan manusia yaitu interaksi intersubyektif. Melalui dialektika ini maka realitas media sosial dapat dilihat dari ketiga tahapan tersebut. Dalam kehidupan sehari-hari, Berger dan Luckman (1990:29) mengatakan, manusia menggunakan dasardasar pengetahuan sehari-hari; obyektivasi (pengobyektivan) dari proses dan makna subyektif dimana dunia akal sehat intersubyektif dibangun.

Meski konsepsi konstruktivisme telah dikoreksi oleh gagasan dekonstruksi Derrida (1978) dengan melakukan interprestasi terhadap teks, wacana dan pengetahuan masyarakat. Kemudian gagasan tersebut melahirkan tesis-tesis keterkaitan antara kepentingan (interest) dan metode penafsiran (interpretation) atas realitas sosial (Nugroho: 1999)

Gagasan Derrida sejalan dengan Habermas (1972), dimana mereka berpendapat bahwa terdapat hubungan strategis antara pengetahuan manusia baik yang bersifat empiris-analisis, histori-hermeneutik, maupun kritis dengan kepentingan yang bersifat teknis, praksis atau emansipatoris. Meskipun itu semua dapat terjadi sebaliknya (Foucoult: 1977) dimana pengetahuan adalah produk kepentingan.

Pengetahuan yang dimaksud adalah realitas sosisal masyarakat. Realitas sosial tersebut adalah pengetahuan yang bersifat keseharian yang ada dimasyarakat. Realitas sosial dikonstruksi melalui proses eksternalisasi, obyektivasi, dan internalisasi. Konstruksi sosial tidak berlangsung diruang hampa, namun sarat dengan berbagai kepentingan.

\section{Internet sebagai Media Komunikasi Termediasi}

Internet sudah bukan menjadi barang asing lagi diantara kita. Temuan teknologi terkini tersebut telah merambah ke seantero dunia dengan cepat dan mempengaruhi kehidupan kita. Melalui internet dengan dunia cyber nya (cyberspace) bisa dikatakan bahwa manusia telah sampai pada sebuah penjelajahan global melampaui batas-batas yang tidak mungkin dilakukan pada abad sebelumnya. Internet dewasa ini dianggap sebagai penyelesaian masalah terhadap segala keterbatasan manusia untuk mengembara dalam berbagai bentuk realitas tanpa batas (Astar Hadi:2005:4) 
Dunia cyber menjadi dunia baru layaknya dalam kehidupan nyata menawarkan hal-hal yang bisa dilakukan pada dunia nyata. Mulai dari chatting, conference, berbelanja sampai mencari jodoh bisa dilakukan di dunia maya ini, bahkan kuliahpun saat ini bisa dilakukan melalui dunia maya ini. Dunia berada diujung jari kita, memasuki "ruang" dimana kita bisa mencari apa saja yang kita inginkan, memasuki "komunitas" yang memiliki minat yang sama dengan kita, atau malah membentuk "komunitas" baru sesuai dengan keinginan kita, tidak dibatasi oleh jarak dan waktu yang di sebut oleh Mc Luhan sebagai "Global Village".

Sebetulnya apa yang dimaksud dengan cyberspace? Sebagai sebuah fenomema baru dalam jagat raya informasi dan komunikasi global, cyberspace menjadi sulit didefinisikan secara untuh. Hal ini di karenakan kecenderungan sifatnya yang plural dan dipenuhi oleh over produksi citra, simbol, dan tanda-tanda yang sarat makna yang seringkali tumpang tindih (Astar Hadi : 2005). Istilah cyberspace pertama kali dipakai oleh William Gibson dalam novelnya Neoromancer, dalam novel tersebut Gibson menggambarkan cyberspace sebagai pemandangan yang dihasilkan komputerkomputer yang di tancapkan langsung yang kadang-kadang juga berupa soket-soket yang langsung di tanamkan di otak (Antariksa : 1999). Bagi Gibson bukan sistem jaringanya yang menjadi penting akan tetapi cyberspace adalah sebuah pengalaman masyarakat yang memakai teknologi baru untuk melakukan sesuatu yang sebenarnya secara genetik telah di programkan yaitu komunikasi. Cyberspace menerangkan sebuah tempat yang tidak ada di manapun, di mana e-mail hilir mudik, transfer elektronik dan pesan-pesan digital lainya berlalu lalang dan situs-situs World Wide Web (www) diakses. Ogden menggambarkan cyberspace sebagai suatu tempat tanpa ruang secara konseptual di mana kata-kata, hubungan antar manusia data, status dimunculkan oleh orang-orang yang menggunakan teknologi komunikasi dengan perantara komputer (Barker 2000: 327), cyberspace sebagai bentuk jaringan komunikasi dan interaksi global (Hadi:2005:7), sedang Yasraf Amir Piliang (2004:16) mendefinisikan sebagai ruang halusinatif yang dibentuk melalui media digital, yang menghasilkan pengalamanpengalaman halusinasi. Cyberspace dengan bangga menawarkan system nilai dan bentuk komunitas sendiri, yaitu yang disebut komunitas virtual.

David Bell dengan meminjam konsep Christine Hine (2000) melihat bahwa kita dapat memakai pendekatan 'culture' dan 'cultural artefak' untuk melihat cyberspace dimana tadinya internet dianggap sebagai model komunikasi sederhana dibandingkan dengan komunikasi secara langsung face to face (Baym,1998). Bahwa interaksi face-to-face tidak hanya melibatkan teks sebagai simbol atau tanda dalam berinteraksi semata. Ekspresi wajah, tekanan suara, cara memandang, posisi tubuh, agama, usia, ras, dan sebagainya merupakan tanda-tanda yang juga berperan dalam interaksi antar individu.

Dalam komunikasi termediasi
komputer atau Computer Mediatied
berdasarkan teks semata bahkan emosipun ditunjukkan dengan menggunakan teks, yakni dengan simbol-simbol dalam emoticon. Selanjutnya Bell mencoba mendekati cyberspace dengan pemahaman bahwa ruang siber tersebut merupakan kombinasi dari tiga hal, yakni material, simbolik, dan dimensi pengalaman. Bell (2001:2) bahkan memberi penekanan bahwa pengalaman di dunia cyber dengan semua spektakuler dan kehidupannya dimanifestasikan dengan memediasi material dan simbolik. Bahkan memikirkan apa itu dan makna dari ruang cyber itu sendiri melibatkan hypertextuality, sebagaimana campuran dan gabungan dari perangkat keras/hardware, perangkat lunak/ software, dan perangkat pendukung yang bisa menyimpan data, meramalkan, memberi harapan maupun ketakutan, juga keberhasilan dan kegagalan. Oleh karena itu menurut Bell, cyberspace adalah kultur yang hidup dan tengah berlangsung, dihasilkan oleh individu 
Made Dwi Adnjani

maupun komunitas, mesin, dan kisah-kisah yang terjadi dalam kehidupan sehari-hari (Nasrullah: 2012).

Kita sedang berada pada sirkuit dimana kita dituntut untuk berpacu menerima dan mereproduksi informasi-informasi baru. Sehingga sangat sulit lagi di bedakan mana informasi-informasi yang asli dan mana yang salinan. Hampir tidak ada lagi originalitas sebuah informasi. Dengan jaringan kerja yang begitu luas dan kemampuan akses yang cepat dengan jarak yang luas teknologi ini menawarkan sisi lain dari komunikasi yang mendunia. Sekali lagi dari ujung jari kita bisa mengirmkan, mengkopi atau mendownload informasi bersamaan dengan munculnya informasi itu sendiri.

Internet dalam sifatnya sebagai media informasi yaitu media yang sama-sama tertuju pada khalayak dan kemajemukan yang luas tidak dapat dipisahkan dengan media komunikasi massa lainya (misalnya televisi, surat kabar, radio, dsb), akan tetapi ada perbedaan karakteristik yang cukup signifikan antara internet dan media-media informasi lainya. Sejak teknologi ini dikembangkan pada sekitar era 80 an disamping kemampuanya menyediakan perubahan informasi yang radikal dan universal dengan jaringan kerja yang begitu luas dan kemampuan akses yang begitu cepat internet menawarkan sisi komunikasi yang mendunia (Hadi:2005). Pada dasarnya kemampuan internet dalam menciptakan realitas virtual atau pengalaman ruang yang dihasilkan oleh teknologi computer terdapat juga pada teknologi televisi, telepon atau film. Tetapi internet menampilkan virtualitas yang berbeda, dimana kontrol atau kendali komunikasi terletak pada pemakai (user) bukan pada pencipta atau medium komunikasi. Sifatnya yang senantiasa on line tentu saja membawa pada sifat interaktif dimana memungkinkan semua pihak dapat berhubungan dan berinteraksi setiap saat, yang memungkinkan partisipasi pemakai begitu tinggi dan kompleks.

Karenanya sebagai artefak kebudayaan (cultural artefac) internet tidak hanya bisa dipahami sebagai sekumpulan komputer yang berinteraksi dengan bahasa komputer itu sendiri, yakni TCP/IP. Kata 'Internet' bisa didenotasikan sebagai seperangkat program komputer yang memungkinkan user untuk melakukan interaksi, memunculkan berbagai macam bentuk komunikasi, serta untuk bertukar informasi. Perkembangan program seperti E-Mail, IRC, bulletin boards, MUDS, video konferensi, dan kemunculan WWW atau World Wide Web merupakan bukti dari semua itu.

Kehadiran individu sebagai objek bisa diwakili dengan animasi (avatar) sesuai dengan keinginan kita; dan di internet siapapun bisa mejadi siapa atau apa yang diinginkannya. Inilah yang pernah diteliti oleh Sherry Turkle (1984) yang mempublikasikan penelitian dalam 'second life' yang menggambarkan bagaimana layar komputer telah menjadi bagian yang tidak terpisahkan dalam relasi individu. Bahkan Sharp (1993) menyatakan teknologi komunikasi telah meluaskan pengertian waktu dan jangkauan dalam relasi antarindividu menggunakan cara berkomunikasi baru dengan teknologi informasi. Inilah yang menurut Holmes (2005:4) bahwa internet merupakan tonggak dari perkembangan teknologi interaksi global di akhir dekade abad ke-20 yang mengubah cakupan serta sifat dasar dari medium komunikasi. Transformasi ini yang disebut sebagai 'second media age', dimana media tradisional seperti radio, Koran, dan televise telah banyak ditinggalkan oleh khalayak.

\section{Identitas Dunia Nyata Vs Identitas Dunia Maya}

Beberapa prasyarat harus dilalui sebelum kita melakukan interaksi dan komunikasi di dunia maya. Prasyarat tersebut memastikan bahwa kita sebagai manusia eksis di dunia nyata. Prasyarat pertama sebelum kita melakukan interaksi melalui internet adalah memasukkan user name dan password (login). Saat ritual tersebut dilakukan maka individu akan mendapatkan ruang pribadi yang dapat 
diakses oleh individu tersebut yang disebut akun. Memasuki dunia maya kadangkala juga melibatkan keterbukaan dalam identitas diri, sekaligus mengarahkan bagaimana individu mengidentifikasi dirinya sendiri dan mengkonstruksikan dirinya didunia maya. Sebagai misal, pengguna facebook harus memberikan informasi seperti nama, tanggal lahir, hobi, pendidikan dan sebagainya. Informasi ini tidak hanya bisa dakses oleh pemilik akun tetapi juga oleh sumua orang yang terhubung jaringan internet (Jordan :1999).

Dalam interaksi virtual setiap individu memiliki kemampuan tanpa batas untuk mengkreasikan siapa dirinya yang nantinya akan berperan dalam interaksi di dunia maya. Membuka identitas individu dengan jujur atau tidak adalah sebuah pilihan, tidak ada larangan siapa menjadi apa dalam dunia virtual. Ketika individu telah melakukan identifikasi dan terhubung dengan di dunia maya, maka identitas itulah yang kemudian menjadi identitas virtual dengan segala atributnya.
Menurut Jordan (1999), ada tiga elemen dasar kekuatan individu di dunia maya yaitu; identity fluidity, renovated hierarchies, dan information is reality. Identity fluidity dalah sebuah proses pembentukan identitas secara virtual dan identitas yang terbentuk tidak harus sama atau mendekati identitas dunia nyatanya. Renovated hierarchies merupakan sebuah proses dimana hirarki- hirarki yang terjadi didunia nyata (offline hierarchies) direka bentuk menjadi on line hierarchy. Akhirnya, hasil akhir dari identity fluidity dan renovated hierarchies inilah lalu menjadi informational space, yaitu informasi yang menggambarkan realita yang hanya berlaku di dunia virtual.

Kenyatan ini memperlihatkan bahwa identitas individu pada dunia virtual memiliki dua kemungkinan yaitu bisa jadi sama atau berbeda secara offline.

\section{Profil Informan}

Penelitian ini adalah penelitian kualitatif dimana dipilih informan remaja usia 13-18 tahun yang aktif di media sosial

Facebook. Data lengkap tentang informan akan disamarkan sehingga tidak menimbulkan exploitasi dan intimidasi pemilik akun.

Secara ringkas, tabulasi informan pada penelitian ini adalah :

\begin{tabular}{|l|l|l|l|l|}
\hline Nama Akun & Usia & Domisili & Status dalam FB & Jenis Kelamin \\
\hline Ian vs ipank & 15 & Semarang & In relationship with............. & L \\
\hline Puput cemumut & 15 & Semarang & Enggaged with... & P \\
\hline Vernaimetal & 16 & Semarang & It's Complicated & P \\
\hline
\end{tabular}

Informan yang diambil adalah informan yang mempunyai pertemanan dan aktif menggunakan akun FB. Mereka saling menandai dan memberikan komentar apabila diantaranya mengunggah status. Hal ini penting untuk melihat bagaimana proses membangun identitas didunia virtual dipengaruhi lingkungan sosialnya. Peneliti mengambil dua informan untuk diwawancara dan dilakukan pengamatan dlam kehidupan off line (nyata), sebagai gambaran tentang perilaku pemilik akun Ian Vs Ipank.

Sehari-hari bersekolah di salah satu SMP swasta di Semarang. Ayah bekerja sebagai wirausahawan dan ibunya sebagai ibu rumah tangga. Sebagai anak sulung dari empat bersaudara Ian Vs Ipank mendapatkan porsi perhatian yang lebih sedikit dibandingkan adik-adiknya. Di sekolah dia merupakan anak dengan kemampuan akademik rata-rata dan 
mengikuti kegiatan ekstra olah raga.

Selain disekolah waktunya dihabiskan di play station dan warnet game online. Pergaulan di rumah lebih banyak diluar rumah dengan pemuda-pemuda diatas usianya. Di akun FB nya dia me "like" beberapa fanpage diantaranya music underground, wiki metal, OBLO (Organisasi Bocah lali Omah), dan Cerita dewasa Indonesia. Didunia maya tertulis status dia bertunangan dengan pemilik akun puput cemumut, di dunia nyata dia berhubungan dekat atau pacar dengan pemilik akun ini. Selanjutnya dari jejaring pertemanan tersebut peneliti melihat intensitas hubungan dengan pemilik akun dari frekuensi komentar.

\section{Kategori Identitas Virtual Remaja}

\section{Status hubungan interpersonal}

Status hubungan interpersonal ini dilakukan remaja bisa dilakukan secara terus terang atau dengan bahasa yang terselubung yang ditujukan kepada seseorang. Inipun dapat dikategorikan lagi ke dalam beberapa group tergantung tujuan dari status tersebut.

a. Hubungan dengan pacar atau seseorang yang di sukai

Beberapa contoh dari status hubungan interpersonal dengan pacar atau seseorang yang disukai:

o Saya mencintai dngan segala kesabaran dan keikhlasan hatiku:-*

- mencintai dengan melihat segala kelebihan dan kekurangan yg dia miliki - with Ian Vs Ipank.

- Salah satu contoh image posting

- aku yang rela terluka untuk masa lalu, aku mau mndampingi diri mu,aku mau cintai kekurangan mu,

- pengen karo kuwe neh,,\#rindu

- baru ku sadari cintaku bertepuk sebelh tangan,

- seneng bisa ktmu kamu,di smansagu.. bisa bersanding di sampingmu..

- .. Hmm ktmu per

- Uy gila cuy gw malam ini gk bisa tidur karna ngelintin facebook cewek gw L $\square \square \mathrm{a} \square \square \square \square$ photo berduaan di pantai mesra bangetzzZZZzzzzzzZZ

- Dan kau hdir, merubh sgala.a Menjdi lebh indah..kau bwa cintaq, stggi angkasa. Membuat q merasa sempurna.

- Tuhan bntu aku untuk menemui dy tapi jauh rumahnya di tangkit kangen aku ama dy.....

- Inget masa2 dulu waktu bareng dg kamu, konvoi bareng temen2, mewek dipundak kamu kalo setiap ada masalah, makan nasi kotak 1 kotak bedua saking irit nya kita minum aja 1 gelas bedua semua nya be.2 (joinan)

- $\quad$ kangen masa2 yg dulu bukan yang sekarang

- pacar lo bekas gua woy ! nyadar diri kenapa muka kayak pinggiran ketek aja betingkah

- malem ini jadwal nya begadang with pacar kesayangan gw ! Hhhha — with Thiiara Chantii Tikista.

- Gamau pisah sama kamu, pengen nya jalan kemana-mana bareng kamu, soal nya kamu orang yang paling ngrtiin akku:*

- Status yang ditujukan untuk teman/ guru/ lingkungan

o woooi........yok bukber....... sekalian kangen2an gitu.......

o nilaiku b.indonesia......sungguh menyedihkan banget....

o free gua wihh, MOS nya udah selesai, udah ga nyubuh lagi deh sekarang brangkat nya

o Di depan orang bisa tersenyum 
seakan-akan tak menderita !

- didepan orang nampak ceria dibalik kau malu.

- tmen gw"febry"lge sedih, tmen gw "putra"lge seneng, dan gw sendiri gak tau lge seneng apa lge sedih, — with Febriieansyah HaruzuQue and Putrha LiieZerr.

- jangan merasa kau yng paling sempurna karna di dunia ini gak ada yng sempurna....

\section{Remaja dan Teknologi}

Perkembangan teknologi informasi telah mempengaruhi masyarakat secara keseluruhan. Perubahan sosial, ekonomi dan buadaya berlangsung secara cepat. Teknologi saat ini bagai pisau bermata dua, dimana pada satu sisi memberikan kontribusi bagi peningkatan kesejahteraan dan peradaban manusia, pada sisi lain teknologi dapat menjadi sarana efektif bagi perbuatan melanggar hukum. Semakin hari kian marak terdengar berita tentang kasus-kasus pornografi melalui dunia maya, pembobolan rekening, penculikan yang berawal dari pertemanan disitus facebook dan lain sebagainya.

Facebook sebagai media sosial yang dianggap paling user friendly dan banyak digunakan oleh masyarakat luas dapat mempengaruhi perilaku keseharian remaja yang masih labil. Facebook oleh remaja seringkali dipakai untuk menunjukkan identitas remaja yang cenderung bebas. Karakteristik pengguna facebook remaja dapat dilihat perkataan dan perbuatan remaja dalam pemanfaatan FB. Status yang diunggah, profile picture, dan foto yang diunggah adalah alat yang dapat dipakai untuk melihat bagaimana identitas remaja dibangun. Selain itu durasi dan frekuensi serta alat yang dipakai untuk mengakses FB juga mempengaruhi perilaku remaja.

Perilaku remaja ini dapat dipengaruhi sekaligus juga mempengaruhi lingkungan dimana saat semua teman-teman sekitar menggunakan FB, mereka akan melakukan hal yang sama. Hal ini tidak selalu buruk. FB memberikan kesempatan bagi remaja untuk mencari teman baru atau mempererat hubungan dengan teman yang sudah ada. Melalui FB remaja juga dapat mengakses berbagai informasi, pengetahuan dan pengalaman baru.

Karakteristik teknologi baru yang dapat menimbulkan efek adiksi bagi pemakainya akan mempengaruhi sikap remaja, misalnya dalam dunia nyata seorang remaja dapat saja anti sosial, pendiam dan tidak banyak berbicara, akan tetapi sangat aktif di FB. Pemberian mata pelajaran TIK bagi pelajar SMP, menambah minat remaja berselancar di dunia maya dikarenakan remaja pada usia SMP telah mempunyai pemikiran oprasional formal dan logis (Judhita :2011).

Data yang diperoleh peneliti menunjukkan bahwa facebook (FB) merupakan situs yang paling sering digunakan oleh remaja, yang kemudian disusul oleh twitter. Informan beralasan selain mudah penggunaanya, FB memungkinkan mereka untuk mengunggah foto, menuliskan status dan menandai teman-teman mereka. Seluruh informan pada penelitian ini membuka facebook sejak 2009 dan 2010. Pada awalnya mereka membuka akun FB melalui warnet atau internet sekolah saat pelajaran TIK. Saat ini semakin handphone baik yang biasa ataupun smartphone serta berbagai provider memungkinkan mereka beraktifitas di FB melalui perangkat bergerak.

\section{Remaja dan Status FB}

Tidak dapat dihindari keasyikan ber FB menjadikan remaja menjadi lebih "individualis". Remaja lebih banyak berinteraksi dengan bahasa text melalui komentar, status dan gambar yang diunggah. Terlihat bahwa pola interaksi teman sebaya pun mengalami pergeseran.

Dari pengamatan yang dilakukan peneliti, status yang diunggah terkadang sesuatu yang seperti kekesalan, curahan hati, 
dan kejadian sehari hari. Misalnya : jengkel, kesal, kangen, pusing, dll. Selain itu remaja juga sudah secara terbuka mengumumkan status hubungan dengan lawan jenis, misalnya "in relationship with" dengan menandai teman dekatnya, atau "enggaged with". Status yang diunggah pun terbuka mulai dari status yang mengungkapkan rasa cinta, marah yang di tandai langsung ke pasangan mereka. Sebagai contoh :

Saya mencintai dngan segala kesabaran dan keikhlasan hatiku:-*

mencintai dengan melihat segala kelebihan dan kekurangan yg dia miliki — with Ian Vs Ipank

\section{Atau}

memang semua slah q mnghiati cinta suci mu,,ttapi saat itu cobaan selingkuh.,

Selain itu remaja juga sering kali mengunggah foto diri maupun foto bersama rekan-rekan. Seringkali remaja ingin secara langsung mengumumkan curahan hatinya, atau mengunggah foto dengan pasangan mereka untuk menunjukkan "status" mereka. Tak jarang komentar-komentar dari teman-teman di FB turut melegitimasi. Dalam sosiologi, setiap kelompok atau masyarakat memiliki nilai acuan yang mengatur anggotanya. Seperti realitas sosial lainya, maka proses konstruksi remaja dalam membangun identitas memiliki nilai acuan yang bersumber pada kelompok remaja itu sendiri.

\section{Konstruksi Identitas Remaja}

\section{Eksternalisasi Identitas Remaja}

Identitas remaja pengguna FB dieksternalisasikan oleh remaja kedalam sosiokultural secara virtual. Eksternalisasi ini terjadi karena adanya kedekatan dan akses antara pengguna dengan teknologi. Bisa dikatakan bahwa remaja lebih mudah untuk beradaptasi dengan perkembangan teknologi. Disaat hubungan didunia nyata semakin berkurang, ketergantungan remaja akan sebuah media untuk eksisistensi semakin bertambah.

Ketergantungan remaja akan dan teknologi seperti di atas akan mempermudah proses eksternalisasi identitas remaja melalui status-status atau gambar yang diunggah di FB. Remaja setiap saat berupaya menyesuaikan diri dengan acuan-acuan nilai yang dilihat melalui status-status remaja lainyadalam dinding FB, acuan-acuan inilah yang kemudian menjadi mind frame (Bungin:2008) remaja yang selanjutnya disimpan menjadi angan-angan mereka.

Mengunggah status menjadi ritual penting bagi remaja dalam kehidupan sosiokultural di dunia maya, karena tanpa disadari remaja berusaha beradaptasi dengan status-status lain yang menjadi acuan nilai remaja.

\section{Obyektivasi Nilai 'status"}

Pada tahap kedua dari siklus konstruksi Berger (1990) adalah obyektivasi. Dalam tahap ini baik status yang diunggah remaja pada akun FB nya dan individu yang menerima atau membaca dan merespon status tersebut berada dalam dunia intersubyektif yang dilembagakan (Bungin: 2008). Obyektivasi ini dapat terjadi tanpa harus bertatapan langsung. Remaja menyerap, mencermati status-status teman sebaya dalam dunia intersubyekti FB.

Hal penting dalam obyektivasi adalah signifikasi, sebagaimana disampaikan Berger dan Luckmann (1990), siginifikasi dibuat oleh manusia, yaitu individu dalam dunia intersubyektif dalam hal ini pengunggah status dan pembaca status dalam dinding FB.

Ketika status diunggah dalam bahasa text, maka terjadi signifikasi text. Signifikasi oleh pembaca text status akan tergantung pada tingkat pengetahuan kelas mereka dimana subyektivitas akan beramain. Disini akan terjadi diskursus antara pengunggah status dan pembaca yang dalam bahasa lain disebut juga sebagai decoding. Secara tidak langsung, signifikasi terhadap status yang diunggahmengerucut kepada sebuah pola 
Made Dwi Adnjani

tipifikasi, yaitu pengetahuan yang spesifik terhadap status pengguna FB (Bungin:2008)

Status yang diunggah remaja diyujukan kepada masyarakat dunia maya menunjukkan ekspresi kebebasan, pergaulan, kesamaan hoby, dan hubungan pertemanan (misal pacar atau teman kencan, dsb). Dari penjelasan diatas, dapat dilihat bahwa objektivasi konstruksi identitas terjadi saat pembaca status melakukan penandaan atau simbol-simbol terhadap status yang diunggah, kemudian baik pengunggah dan yang membaca melakukan tipifikas yaitu memahaminya secara segmentasi.

\section{Reproduksi Sosial dan Internalisasi Nilai}

Status-status yang diunggah remaja seperti " aq gi cebel" (baca: aku sedang sebal), atau Susah memungkiri bahwa aku masih sangat menyayangimu, Didalam benakku dan didalam asaQ .., Bagimu aku hanyalah sepenggal kisah sejenakmu, tapi kamu adlh yg slalu dibenak dan rasaQ, Till the end atau pada lain kesempatan Save me in your heart atau padahal aku yo wes ngalah, tp kok yo msh dijahati trs dasar kamu ki a*u :@. Beberapa status tersebut menggambarkan ekspresi remaja yang merupakan realitas sosial. Mereka menuliskan status-status tersebut biasanya berkenaan dengan perasaan hati dan ditujukan kepada seseorang seolaholah senyatanya terjadi interaksi di dalamnya. Dengan kata lain, status-status yang diunggah bukan dengan tiba-tiba hadir dari ruang hampa melainkan lahir dari realitas sosial kelompok remaja yang merupakan bagian dari reproduksi sosial. Hubungan sosial tergambarkan melalui teks dalam status yang diunggah, bahwasanya banyak ekspresi yang direfleksikan ke dalam text status pada dinding FB.

FB sebagai media transaksional dan interaksional yang dikonsumsi secara masif, mempunyai kemampuan luar biasa dalam mereproduksi nilai-nilai yang dibangun dalam status FB kedalam realitas sosial remaja. Dalam pengamatan yang mendalam pada status remaja yang diunggah dalam dinding FB individu maupun dengan menandai pada dinding orang lain terlihat bagaimana statusstatus tersebut memproduksi nilai-nilai kebebasan berekspresi, dimana pada beberapa budaya tertentu kebebasan ini dapat diperoleh melalui ekspresi verbal. Bagi remaja yang berada pada budaya yang lebih tertutup maka status-status degan ekspresi kebebasan telah memproduksi nilai-nilai baru yang memperbolehkan mengeksprsikan perasaan, suasana hati secara terbuka.

Kekuatan FB secara massif dan membabi buta menjejali setiap detik para remaja, menjadikan remaja tidak mampu lagi memfilter dalam kehidupan mereka sehingga menganggapnya sebagai tanda keterbukaan, kemodernan sebagaimana ciri-ciri perubahan sosial itu sendiri.

\section{Identitas Remaja dalam Interaksi}

Kehadiran FB tidak dapat dipungkiri telah membawa fokus baru, terutama di kalangan remaja dalam mengkonstruksi identitas mereka secara on line. Frekuensi terunggahnya status sampai dengan lebih dari lima kali dalam durasi 8 jam, menunjukkan bahwa identitas bukan hanya sekedar proses, tetapi juga konstruksi identitas itu sendiri yang berlangsung dinamis dan simultan (Nasrulah:2012). Pada dasarnya setiap aktivitas individu melibatkan partisipasi dari individu lainya. Facebook memungkinkan remaja meperoleh respon dan pengakuan secara cepat dalam wacana sosial. Misalnya apabila remaja mengunggah status yang berhubungan dengan suatu peristiwa yang terjadi, dia berharap akan mendapatkan respon positif dari komunitasnya.

Sebagaimana disampaikan Wollam dalam Nasrulah (2012), bahwa FB merupakan penggambaran sempurna tentang bagaimana sebuah teknologi mampu mendorong dan mneyediakan ruang bagi setiap individu dalam mengkonstruksi diri mereka.

Interaksi secara virtual yang yang dilakukan oleh remaja kemudian menghasilkan apa yang disebut dengan self devinition yang menawarkan self invention (Nasrulah: 2012). 
Made Dwi Adnjani

Setiap individu mempunyai kemampuan tak terbatas untuk membentuk siapa dirinya dalam dunia cyber. Hasil bentukan atau kreasi itulah yang selanjutnya akan mewakili individu dalam memainkan peranya dan seacara terus menerus berinteraksi secara virtual.

Kenyataan membuktikan bahwa identitas individu pada FB memiliki dua kemungkinan yakni bisa jadi sama atau berbeda secara online dan off line. Individu tidak hanya memiliki satu identitas, melainkan dapat memiliki identitas beragam dengan karakteristik yag berbeda (Stone 1999 dalam Nasrullah :2012). Selanjutnya Stone menegaskan bahwa teknologi memungkinkan terjadinya interaksi antar individu dari belahan dunia manapun namun komunikasi masih terbatas oleh text.

Berkaitan dengan virtual interaksi yang membentuk perilaku komunikasi, Marc Smith (1995) memberikan empat aspek penting; a). Virtual interactions is aspatial, bahwa jarak tidak memengaruhi proses komunikasi dan interaksi. Kehadiran atau kedekatan jarak tidak menjadi penting selama masing-masing dapat menjalankan fungsinya; b) Virtual interaction via system is predominantly asynchronous. Pengecualian dalam memakai Chat, MUDs, atau ICQs bahwa komunikasi melalui komputer seperti konferensi sistem, dan email dapat dioperasikan berdasarkan waktu atau jadwal yang diinginkan; c) $C M C$ is acorporeal because it is primarily a text-only medium. Interaksi yang terjadi melalui jaringan komputer pada dasarnya diwakili dengan teks. Efek dari CMC yang asynchronous dan acorporeal ini, sebagai misal, mampu melakukan komunikasi dengan melibatkan jumlah individu yang besar, sedangkan hal ini juga bisa dilakukan melalui konferensi telepon; d) CMC (Computer Mediatied Communication) is astigmatic. Bahwa interaksi yang terjadi cenderung mengabaikan stigma terhadap individu tertentu, sebab komunikasi berdasarkan teks ini sangat sedikit bisa menampilkan gambaran visual tentang status seseorang dibandingkan apabila bertatap muka. Akhirnya, mengutip penjelasan Tim Jordan dalam bukunya Cyberpower (1999) bahwa CMC pada dasarnya anti hirarki sebab identitas individu di cyberspace tidaklah menggambarkan secara utuh hirarki yang terjadi secara off-line. Juga, kapasitas internet yang bisa mencakup dari banyak ke banyak menciptakan inklusifitas dan lingkungan partisipan dimana terdapat kultur pengecualian yang sulit mendukung bahwa inilah gambaran individu yang sebenarnya di dunia nyata atau off-line life. Problem identitas inilah yang menjadi salah satu isu penting ketika membincangkan CMC.

\section{Simpulan}

Dari hasil penelitian yang dilakukan dapat disimpulkan bahwa :

1. Perangkat Facebook memungkinkan setiap pengguna dan atau pemilik akun di Facebook disediakan form atau borang untuk menuliskan profil diri mereka seperti nama, nama kecil, tempat tanggal lahir, pendidikan, hobi, sampai pada kutipan yang disenangi olehnya. Fasilitas Facebook tersebut memungkinkan seseorang mengkonstruk dirinya melalui perantaraan teks baik itu dalam pengertian kumpulan kata maupun gambar yang pada akhinya memberikan kepingan-kepingan gambar bagaimana subyek pemilik akun Facebook itu.

2. Meski Facebook memiliki kuasa untuk mengarahkan bagaimana informasi apa saja yang harus disampaikan oleh subyek tersebut, namun pilihan untuk memberikan informasi tersebut tetap kembali kepada kesadaran pengetahuan dari pengguna facebook tersebut karena pada praktiknya ruang konstruksi identitas ini bisa bersifat opt in (hanya dibaca oleh pemilik akun itu sendiri, sebagian teman dalam jaringan Facebook, atau teman dari teman dalam jaringan Facebook) atau opt out (yang bisa dibaca oleh siapapun juga).

3. Facebook sebagai media transaksional dan interaksional yang dikonsumsi secara masif, mempunyai kemampuan luar biasa 
dalam mereproduksi nilai-nilai yang dibangun dalam status facebook ke dalam realitas sosial remaja.

4. Identitas diri remaja di Facebook cenderung membebaskan dirinya dari pemahaman kesejarahan tentang identitas yang selama ini berlaku di dunia nyata, maka orang tua juga perlu untuk lebih memahami teknologi sehingga memungkinkan untuk melakukan pendampingan dan pemantauan terhadap konstruksi identitas yang dibentuk anakanaknya.

5. Identitas remaja dalam facebook yang cenderung menjadi Identity fluidity atau identitas yang tidak sama atau mendekati dengan identitas di dunia nyata (offline identities) maka perlu ditanamkan kesadaran pada remaja untuk lebih mengutamakan kejujuran dibandingkan dengan kebohongan semu yang tidak akan membawa manfaat bagi kehidupannya di dunia nyata.

\section{Daftar Pustaka}

Antariksa. 1999. "Cyberculture". Dimuat dalam newsletter KUNCI no 2, September 1999 dapat di akses di http://www.kunci.or.id/esai/nws/02/ cyberculture.htm

Barker, Chris.2004,"Cultural Study”. Yogyakarta: Kreasi Wacana

Bell, David. 2001. An Introduction to Cyberculture. London-New York: Routledge

Berger, Peter. L. 1991, Langit Suci: Agama Sebagai Realitas Sosial, Jakarta: LP3ES

Berger, Pam, Are You Blogging Yet?, Infromation Searcher 14 No.2, 2003

Derlaga, Valerian J. and Berg, John H. SelfDisclosure: Theory, Research and Therapy (Perspectives in Social Psychology). New York: Plenum
Press

Erikson, Erik H. 1989, identitas dan Siklus Hidup Manusia. Bunga Rampai I, Penerjemah: Agus Cremers. Jakarta: PT. Gramedia

Fearon, James D. 1999. What Is identity (As We Now use the World), unpublished

Foucault, Michel. 1969. The History of Sexuality: An Introduction. London and Worcester: Guilford Billing \& Sons Ltd

, Michel. 1977. Discipline and Punish: the Birth of the Prison (transl. AlanSheridan). London: Allen Lane the Penguin Press.

Fukuyama, Francis.2002. The Great Disruption, Hakikat Manusia Dan Rekonstruksi Tatanan Sosial”. Yogyakarta :Qalam

Hadi, Astar. 2005. "Cyberspace, Kritik Humanis Mark Slouka Terhadap Jagat Maya”. Yogyakarta : LKIS

Hurlock, Elizabeth.B. 1999. Psikologi Perkembangan: Suatu Pendekatan Sepanjang Rentang Kehidupan. Edisi kelima. Alih Bahasa oleh: Dra. Istiwidayanti \& Drs. Soedjarwo, M.Sc. Jakarta: Erlangga

Kamaluddin, Laode Masihu, 2011. "Goes beyond technological frontier,The application of mobile learning as a pathway to digital revolution in education", Makalah Presentasi disampaikan pada forum Indo Global Education Summit, India:2011

Krahe. B. 2001. The Social Psychology of Aggresion, alih bahasa oleh Helly Prajitno Soetjipto dan Sri Mulyani Soetjipto. Yogyakarta: Pustaka Pelajar.

Muus, r. 1996. Theories of Adolesence. New York: Mc. Graw Hill

Piliang, Yasraf Amir, Realitas-Realitas Semu Masyarakat Konsumer 
dalam"Lifestyle Ecstay, Kebudayaan Pop Dalam Masyarakat Komoditas Indonesia" Ibrahim, Idi Subandy (editor).2004.. Yogyakarta :Jalasutra 2004

, Yasraf Amir. 2004. "Dunia Yang Dilipat, Tamasya Melampai BatasBatas Kebudayaan". Yogyakarta :Jalasutra

Prastiwi, Yunita Dewi. 2009. Hubungan antara Kelekatan terhadaop Orang Tua dengan Identitas Diri pada Remaja pria di LP Anak Kutoarjo (Thesis)

Ritzer, George.2003. "Teori Sosial Postmodern". Yogyakarta: Juxtapose research study bekerjasama dengan Kreasi Wacana
Salim, Agus. 2006, Teori dan Paradigma Penelitian Sosial, Yogyakarta: Tiara Wacana

Santrock, John W. 2001. Life span Development, Jilid 2. Alih Bahasa oleh: Juda Damanik. Jakarta: Erlangga.

_ John W.2003. Adolesence Perkembangan Remaja. Edisi ke Enam. Alih Bahasa oleh Dra. Shinta B, Adelar.M.Sc dan Sherly Saragih,S. Psi. Jakarta: Erlangga.

Watkins,S. Craig. 2009. The Young and The Digital: what the Migration to Social Networksites, Games anytime and Anywhere Media Means for Our Future. UK: Beacon Press. 